\title{
Cortical stimulation and neuropathic pain
}

\author{
Cristiane Cagnoni Ramos ${ }^{1 *}$ \\ Fernanda Cardoso ${ }^{1}$ \\ Carlos Eduardo Malavasi Bruno ${ }^{1}$ \\ Juliana Shimara Pires Ferrão ${ }^{1}$ \\ Joana Mona e Pinto ${ }^{2}$ \\ ${ }^{1}$ Departamento de Cirurgia, Faculdade de Medicina Veterinária e Zootecnia, Universidade de São Paulo \\ Av. Prof. Dr. Orlando Marques de Paiva, 87, CEP 05508-270, São Paulo - SP, Brasil \\ ${ }^{2}$ Departamento de Biologia Celular e Tecidual, Instituto de Ciências Biomédicas \\ Universidade de São Paulo, São Paulo - SP, Brasil \\ * Autor para correspondência \\ cris.cagnoni@gmail.com
}

Submetido em 22/04/2014

Aceito para publicação em 20/02/2015

\section{Resumo}

Estimulação cortical e a dor neuropática. O presente trabalho é uma revisão de dados fisiológicos e comportamentais sobre a estimulação elétrica do córtex motor (ECM) e seu papel durante a dor neuropática persistente. A ECM tem sido amplamente utilizada na clínica médica como ferramenta para controle da dor que não respondem satisfatoriamente a nenhum tipo de analgesia convencional. Alguns importantes mecanismos envolvidos na modulação nociceptiva não foram, até o momento, esclarecidos. O objetivo deste estudo foi descrever os mecanismos envolvidos durante a dor neuropática e apresentar a eficiência da estimulação elétrica do córtex motor utilizada no tratamento desta doença. As vias ascendentes da dor são ativadas por receptores periféricos, onde há a transdução do estímulo químico, físico ou mecânico, em impulso nervoso, transmitindo este até a coluna posterior da medula espinal, onde ocorre conexão com neurônios de segunda ordem e ascendem à diferentes locais do sistema nervoso central, onde o estímulo periférico é percebido como dor. Por ser comprovada grande modulação deste sentido no córtex motor, vem sendo estudado o efeito da ECM para mimetizar os efeitos na pratica clinica e aperfeiçoar os tratamentos empregados durante a dor crônica. A ECM ganhou uma atenção especial nos últimos anos devido a sua ação em reverter quadros de dor neuropática de origem crônica, esta sendo mais eficiente do que a estimulação elétrica em diferentes locais e núcleos relacionados a dor.

Palavras-chave: Córtex motor; Dor neuropática; Estimulação elétrica; Nocicepção

\section{Abstract}

This paper is a review of physiological and behavioral data on motor cortex stimulation (MCS) and its role in persistent neuropathic pain. MCS has been widely used in clinical medicine as a tool for the management of pain that does not respond satisfactorily to any kind of conventional analgesia. Some important mechanisms involved in nociceptive modulation still remains unclear. The aim of this study was to describe the mechanisms involved in neuropathic pain and introduce the effectiveness of electrical stimulation of the motor cortex used in the treatment of this disease. The ascending pain pathways are activated by peripheral receptors, in which 
there is the transduction of a chemical, physical or mechanical stimulus as a nerve impulse, where this impulse is transmitted to the dorsal horn of the spinal cord, which connects with second-order neurons and ascends to different locations in the central nervous system where the stimulus is perceived as pain. Because MCS has been proved to modulate this pathway in the motor cortex, it has been studied to mimic its effects in clinical practice and improve the treatments used for chronic pain. MCS has gained much attention in recent years due to its action in reversing chronic neuropathic pain, this being more effective than electrical stimulation at different locations and related pain nuclei.

Key words: Electrical stimulation; Motor cortex; Neuropathic pain; Nociception

\section{Introduction}

In clinical practice, it has been extensively reported that neuropathic pain is difficult to treat, due to inadequate understanding of the cellular and molecular mechanisms involved in the development and maintenance of this type of pain (D'ANGELO et al., 2013; GASKELL et al., 2014; SAPIENZA et al., 2014) and also because it is a multidimensional experience that functionally integrates limbic and cortical system structures, to start the perception of pain and responses to these injuries (SENAPATI et al., 2005b; PAGANO et al., 2011; BLOM et al., 2014).

Among patients who have some kind of pain, it is estimated that about $27 \%$ suffer from neuropathic pain, where it is not only the most intense kind of pain but also one that corresponds to less conventional treatments (TORRANCE et al., 2006). In a study of 16 patients with neuropathic pain, 7 had no pain relief after application of intravenous morphine, 7 showed little relief, and only 2 patients had complete relief of pain (McQUAY, 2002).

Therapeutic options for the control of neuropathic pain have increased in the last years (JEON et al., 2013; MOINI ZANJANI et al., 2014). However, the response of patients with neuropathic pain to many of the treatments is not satisfactory. The treatments used in clinical practice include tricyclic antidepressants, anticonvulsants, systemic administration of local anesthetics, topical agents, narcotics and non-narcotic analgesics and surgical lesions (SRINIVASAN et al., 2012; THANGAMANI et al., 2013; JAGLA et al., 2014).

Based on the concept that the pain from medical procedures can be altered by cortical modulation, TSUBOKAWA (1990) postulated that electrical motor cortex stimulation (MCS) in humans, for the treatment of central neuropathic pain, would be more effective than sensory cortex and thalamic stimulation, commonly used for the treatment of thalamic pain. Since then, cortical stimulation gained attention because of its good results in the treatment of various pain syndromes, including the ones of neuropathic origin (FONOFF et al., 2009; ALM; DREIMANIS, 2013; MAARRAWI et al., 2013).

Some hypotheses have been proposed regarding the mechanisms involved in the antinociception induced by the use of MCS, suggesting that there is substantial inhibition of most neuronal activity, especially neurons of the dorsal horn of the spinal cord (DHSC) (SENAPATI et al., 2005a; PAGANO et al., 2011; FRANÇA et al., 2013; PORTILLA et al., 2013).

The aim of this study was to describe the mechanisms involved in neuropathic pain, especially persistent peripheral neuropathic pain, and to present the implications and efficacy of electric motor cortex stimulation used in clinical and experimental practice for treating this disease. Thus, a better understanding of the analgesic effect of MCS may contribute to improving clinical treatments used for chronic neuropathic pain.

\section{Transmission of noxious impulse}

The sensation of pain, by its inherent nature, contributes to one of the vital functions of the nervous system, which is to provide information on the occurrence or risk of injury. Pain is a subjective result of nociception, and it is postulated that nociception refers to the neurophysiological manifestation generated by noxious stimuli, while pain involves the perception of an aversive stimulus, which requires the capacity for abstraction and elaboration of sensory impulses (MILLAN, 1999). 
The spread of pain is initiated by the generation of action potentials in primary afferent fibers of small diameter, namely nonmyelinated $\mathrm{A} \delta$ and $\mathrm{C}$ fibers, which have specific pain receptors, called nociceptors. Nociceptors respond to three major classes of stimuli, mechanical, thermal or chemical, and are normally activated by stimuli affecting intensity (ALMEIDA et al., 2004).

The primary afferent neurons, once activated, make direct or indirect connections with intrinsic neurons in the DHSC. Direct connections occur when the primary neuron makes connections directly with projection neurons, which carry nociceptive information to higher brain centers. The indirect connections occur when the primary afferent neurons make connections with excitatory interneurons, which carry impulses to sensory projection neurons, or inhibitory interneurons, regulating (in the spinal cord) the flow of nociceptive information to higher areas of the central nervous system (CNS) (RIEDEL; NEECK, 2001).

Projection neurons carry nociceptive information by different ascending pathways to the brainstem structures and diencephalon (MILLAN, 1999). Among the main supraspinal projections, the spinothalamic tract is the most prominent ascending nociceptive pathway in the spinal cord and projects into the ventral posterior lateral (VPL) and ventral posterior medial (VPM) nucleus involved with discriminative components of pain sensitivity and nonspecific thalamic nucleus (centromedial, centrolateral, laterocentral and intralaminar), related to the affective component of pain (KIM et al., 2013; GHANBARI et al., 2014).

In the thalamus, there is the reception, integration and transfer of nociceptive potential to the cerebral cortex, where the information is organized somatotopically (YEN; LU, 2013). On the basis of functional criteria, the main cortical regions involved in pain response are the motor cortex, primary (S-I) and secondary (S-II) sensory cortex (SCHNITZLER; PLONER, 2000; GUSTIN et al., 2012). However, it has been observed that patients with specific brain lesions, particularly in the SI cortex, are still able to feel pain (BROOKS; TRACEY, 2005), and an intense activity has been seen in the SI cortex of patients with chronic neuropathic pain compared to patients with chronic non-neuropathic pain (GUSTIN et al., 2012).

\section{Pain suppressor system}

Pain may be controlled by central mechanisms, since the nervous system has modulatory circuitry governing the perception of pain. This modulation is initiated in the spinal cord where interconnections between nociceptive and non-nociceptive afferent pathways can control the transmission of nociceptive information to supraspinal centers (FIELDS; BASBAUM, 1999).

The existence of a descending pain modulatory system was first postulated (HEAD; HOLMES, 1911), where this hypothesis was extended with the preparation of the gate control theory.

Thus, it was seen that pre-synaptic inhibition of nociceptive pathways in the spinal cord arise from the potential collision between the primary afferents and antidromic negative potential, generated by inhibitory interneurons present in the gelatinous substance (laminae II and III) of the DHSC. The activation of these interneurons generates negative potentials in the sensory roots, hindering the nociceptive potential from reaching the DHSC. This definition of the gate control theory remains as the current concept of the inhibitory localized pain mechanism that occurs in the DHSC (SHRIVASTAV; MUSLEY, 2009; LU et al., 2013; ARLE et al., 2014).

Subsequently, it was shown that brain structures also exert inhibitory activity on cells of the DHSC, since electrical stimulation of the midbrain periaqueductal gray $(\mathrm{PAG})$ in rats produces analgesia (REYNOLDS, 1969) and considering the existence of opioid receptors in the amygdala, hypothalamus, thalamus and midbrain PAG (CONDÉS-LARA et al., 2009; MAARRAWI et al., 2013). Still, the PAG has many neurons containing enkephalin, substance P (SP) and gamma-aminobutyric acid (GABA), and some of these neurons project to the rostral ventromedial medulla (RVM) (SCHAIBLE, 2004; BAGLEY, 2014).

Among the nuclei of the RVM implicated in the mechanism of pain suppression, those that stand out are the nucleus raphe magnus, rich in serotonergic 
neurons, and the neurons of the reticular formation, which receive projections arising from the PAG, of the posterior hypothalamus and of the locus coeruleus, rich in noradrenergic neurons (BASBAUM; FIELDS, 1984). RVM neurons project from the dorsolateral spinal cord, ending in the spinal cord, which inhibit nociceptive transmission (BASBAUM; FIELDS, 1984).

The DHSC is where the efferent axons of serotonergic and/or noradrenergic neurons contact the projection neurons and inhibitory enkephalinergic interneurons (SUZUKI et al., 2004; HUGHES et al., 2013) and where the activation of GABAergic interneurons inhibits the release of excitatory nociceptive neurotransmitters such as glutamate, substance $\mathrm{P}$ and calcitonin gene-related peptide (MALCANGIO; BOWERY, 1996; KIMURA et al., 2012; OHNAMI et al., 2012).

Still, it was reviewed that the cerebral cortex is capable of activating the descending inhibitory pain system (OHARA et al., 2005). On the other hand, various studies in humans and animals have shown that inhibition or lesion of the cortical area produces analgesia (BURKEY et al., 1999). There is evidence that the cortical regions of the corticospinal tract originating from the motor cortex and cortices S-I and S-II exert an inhibitory effect on neurons of the DHSC (SENAPATI et al., 2005a). Despite the observations suggesting that the relationship between cortical activity and nociceptive threshold, the participation of the cerebral cortex and its projections to structures involved in antinociception is unclear.

The descending control of spinal nociception is the major determinant of acute pain in different behavioral and emotional states (BANDLER; SHIPLEY, 1994). However, it is quite evident that the state of chronic neuropathic pain also depends on the descending inhibitory control that originates in the brain (URBAN; GEBHART, 1999), but its control is currently a significant challenge to medicine.

\section{Neuropathic pain}

The International Association for the Study of Pain (IASP) defines neuropathic pain as pain initiated or caused by a primary lesion or dysfunction in the nervous system and can be classified as central or peripheral, where central pain is from injuries or illnesses that affect the brain or spinal cord, and where peripheral pain is from peripheral nerve changes, causing localized or generalized pain (BARON, 2006).

Such changes include the presence of ectopic foci in damaged peripheral nerve fibers, which maintain the afferent impulses to the CNS. The entry of ectopic impulses or high-intensity and high-frequency impulses promote the release of excitatory neurotransmitters in the spinal cord, such as substance $\mathrm{P}$ and glutamate, sensitizing DHSC neurons (KUMAR et al., 2013; CHEN et al., 2014; WENG et al., 2014).

Neuropathic pain produces a number of changes in the somatosensory pathway, consisting of changes in depolarization and neurotransmitter release and reorganization of synapses. Such changes involve the participation of different algogenic mediators that contribute to decreased pain threshold and increased response to small stimuli, for peripheral sensitization (ZIMMERMANN, 2001).

Peripheral nerve injury results in persistent or chronic neuropathic pain characterized by spontaneous pain, accompanying allodynia (pain in response to stimuli that usually cause no pain) and hyperalgesia (exaggerated pain response to injurious stimuli) (ZIMMERMANN, 2001; PEYRON et al., 2013; JIANG et al., 2014). These sensations can be induced by thermal (heat or cold) and mechanical stimuli (BENNETT, 1994).

During this phenomenon, sensitization of ascending sensory nerve bundles makes them susceptible to stimulation by mechanoreceptors (A $\beta$ fibers) and nociceptors. The phenomenon of allodynia results in some changes that occur throughout the nociceptive pathway, such as reorganization of central afferent and loss of inhibitory mechanisms. Peripheral lesions of C fibers decrease the release of GABA by spinal inhibitory neurons, which contributes to the loss of inhibitory mechanisms of pain control. Furthermore, there is a decreased release of serotonin and norepinephrine by descending inhibitory neurons (CAVIEDES; HERRANZ, 2002; MEYERSON; LINDEROTH, 2006; BUONOCORE et al., 2013; THIBAULT et al., 2013). 
Several studies have shown that in the spinal cord, glial cells are involved in inflammation-induced peripheral pain and neuropathic pain. Centrally, the glia cells are formed by macroglia (astrocytes and oligodendrocytes) and microglia. Oligodendrocytes are the myelin forming cells of the peripheral nervous system (PNS), corresponding to $40 \%$ of glial cells (ZHANG; DE KONINCK, 2006; RISTOIU, 2013). About 50\% of glial cells are astrocytes and only 5-10\% microglia (ZHANG; DE KONINCK, 2006). Specifically after injury-induced peripheral neuropathy, changes occur in the DHSC, for example, expression of neuropeptides, glial cell activation and neuronal hyperexcitability (MATSUO et al., 2014; RICHNER et al., 2014; TIWARI et al., 2014).

Astrocytes and microglia act in the development, induction and potentiation of neuropathic pain. Following peripheral nociceptive activation after nerve injury, microglia become active and release proinflammatory cytokines such as tumor necrosis factor- $\alpha$ (TNF- $\alpha$ ), interleukin-1 $\beta$, and interleukin- 6 , which initiate the nociceptive process. The microglia propagate neuroinflammation to recruit other microglia, such as the activation of astrocytes near the injury site, which prolong the inflammatory state and lead to a condition of chronic neuropathic pain (VALLEJO et al., 2010).

\section{Pain and cortical stimulation}

The concept that pain can be altered by cortical modulation is confirmed by many observations and clinical procedures (SENAPATI et al., 2005a). The study where the use of cortical electrical stimulation for the treatment of neuropathic pain of central origin in humans was first reported (TSUBOKAWA et al., 1990) gave rise to the hypothesis that an electrical impulse could activate sensory neurons present at the stimulation site, thereby leading to inhibition of nociceptive neurons located in the cerebral cortex (TSUBOKAWA et al., 1993). Since then, cortical stimulation gained much attention because of its effectiveness in treating various pain syndromes, including pain of neuropathic origin (VELASCO et al., 2008; ANTAL et al., 2010; TRISTER et al., 2013; JIANG et al., 2014).

In treating thalamic pain, it was seen that electrical stimulation of the thalamus (deep brain) as well as the sensory cortex was generally less effective than stimulation of the motor cortex (TSUBOKAWA et al., 1993). In line with this idea, it was suggested that MCS does not affect the sensory threshold and breakdown component of pain, thus excluding an effect on the upward transmission of information (OHARA et al., 2005).

Experimentally, it has been demonstrated by electrophysiology that inhibition of the activity of DHSC neurons in response to mechanical stimulation, is induced by S-I and motor cortex stimulation, where this effect is observed only during stimulation (SENAPATI et al., 2005a). It was also shown that subdural electrical stimulation of the motor cortex induced antinociception in mice with central neuropathic pain in a thermal hyperalgesia model (RUSINA et al., 2005). Recently, it was also observed that subdural stimulation inhibits thermal hyperalgesia induced by persistent peripheral neuropathy in rats (VACULIN et al., 2008).

The experimental results obtained with MCS differ from those in the treatment of patients with chronic neuropathic pain, where in animal models, the electrodes used for cortical stimulation are implanted subdurally, i.e., deep in the cerebral cortex, or transdurally, which is less invasive than subdural stimulation, since there is no penetration of the cerebral cortex, thereby preventing tissue damage and possible complications, such as hemorrhage, necrosis and postoperative meningitis. Thus, the action of cortical stimulation demonstrates a direct relationship between the somatotopy of the motor cortex and the segment of the body affected by pain, by acting in subcortical regions located near the electrode or in the cortex only (KATAYAMA et al., 1988; ALM; DREIMANIS, 2013; RIDDER et al., 2013).

Mimicking the protocol and to make this more similar to that applied in humans for the best applications, it was demonstrated that transdural electrical stimulation of the motor cortex applied in a single session of $5 \mathrm{~min}$ (amplitude $1.0 \mathrm{~V}$; frequency 60 $\mathrm{Hz}$; pulse duration $210 \mu \mathrm{s} ; 0.1 \mu \mathrm{A}$ of delivered current - AVS Projectos ${ }^{\circledR}$ - Electrical Stimulator, São Paulo, Brazil) increases nociceptive threshold in rats evaluated in the paw pressure model without interfering with motor response of these animals, where this effect is mediated by opioid receptors (FONOFF et al., 2009; FRANÇA et al., 2013). 
Furthermore, it was shown that MCS reverses neuropathic pain, at least in part, in animals subjected to chronic constriction injury of the sciatic nerve by activation of neurons of the PAG, central and basolateral nucleus of amygdale and anterior cingulate cortex, and by inhibition of neurons of the VPM and VPL thalamic nucleus and DHSC, observed by immunostaining of the c-Fos proto-oncogene (PAGANO et al., 2011).

Despite the work positing the direct relationship between antinociception and neuronal activation after stimulation of the motor cortex, further studies involving neuroplasticity are still needed.

These studies may contribute to both a better understanding of the role of the motor cortex in the modulation of neuropathic pain and the improvement of therapeutic strategies in the treatment of persistent pain.

\section{Acknowledgments}

The authors thank Diogo Nader Palermo and Adilson S. Alves for their assistance during fieldwork and Luiz Roberto G. de Britto for relevant suggestions on the manuscript.

\section{References}

ALM, P. A.; DREIMANIS, K. Neuropathic pain: transcranial electric motor cortex stimulation using high frequency random noise. Case report of a novel treatment. Journal of Pain Research, Auckland, v. 6, p. 479-486, 2013.

ALMEIDA, T. F.; ROIZENBLATT, S.; TUFIK, S. Afferent pain pathways: a neuroanatomical review. Brain Research, Amsterdam, v. 1000, n. 1-2, p. 40-56, 2004.

ANTAL, A.; TERNEY, D.; KÜHNL, S.; PAULUS, W. Anodal transcranial direct current stimulation of the motor cortex ameliorates chronic pain and reduces short intracortical inhibition. Journal of Pain and Symptom Management, Madison, v. 39, n. 5, p. 890-903, 2010.

ARLE, J. E.; CARLSON, K. W.; MEI, L.; IFTIMIA, N.; SHILS, J. L. Mechanism of dorsal column stimulation to treat neuropathic but not nociceptive pain: analysis with a computational model. Neuromodulation, Malden, doi: 10.1111/ner.12178, 2014.

BAGLEY, E. E. Opioid and GABAB receptors differentially couple to an adenylyl cyclase/protein kinase A downstream effector after chronic morphine treatment. Frontiers in Pharmacology, Lausanne, v. 5, n. 148, doi: 10.3389/fphar.2014.00148, 2014.

BANDLER, R.; SHIPLEY, M. T. Columnar organization in the midbrain periaqueductal gray: modules for emotional expression? Trends in Neurosciences, Cambridge, v. 17, n. 9, p. 379-389, 1994.
BARON, R. Mechanisms of disease: neuropathic pain - a clinical perspective. Nature Clinical Practice Neurology, Kiel, v. 2, n. 2, p. 95-106, 2006.

BASBAUM, A. I.; FIELDS, H. L. Endogenous pain control systems: brainstem spinal pathways and endorphin circuitry. Annual Review of Neuroscience, Palo Alto, v. 7, p. 309-338, 1984. BENNETT, G. J. Animal models of neuropathic pain. In: GEBBART, G. F.; HAMMOND, D. L.; JENSEN, T. L. (Ed.). Proceedings of the 7th World Congress on Pain. Seattle: Progress in Pain Research and Management, IASP Press, 1994. p. 495-510.

BLOM, S. M.; PFISTER, J. P.; SANTELLO, M.; SENN, W.; NEVIAN, T. Nerve injury-induced neuropathic pain causes disinhibition of the anterior cingulated cortex. The Journal of Neuroscience Online, Washington, v. 34, n. 17, p. 5754-5764, 2014. BROOKS, J.; TRACEY, I. From nociception to pain perception: imaging the spinal and supraspinal pathways. Journal of Anatomy, London, v. 207, n. 1, p. 19-33, 2005.

BUONOCORE, M.; GAGLIANO, M. C.; BONEZZI, C. Dynamic mechanical allodynia following finger amputation: unexpected skin hyperinnervation. World Journal of Clinical Cases, Hong Kong, v. 1, n. 6, p. 197-201, 2013.

BURKEY, A. R.; CARSTENS, E.; JASMIN, L. Dopamine reuptake inhibition in the rostral agranular insular cortex produces antinociception. The Journal of Neuroscience, Washington, v. 19, n. 10, p. 4169-4179, 1999.

CAVIEDES, B. E.; HERRANZ, J. L. Advances in physiopathology and the treatment of neuropathic pain. Revista de Neurologia, Barcelona, v. 35, n. 11, p. 1037-1048, 2002.

CHEN, W.; McROBERTS, J. A.; MARVIZÓN, J. C. $\mu$-Opioid receptor inhibition of substance $\mathrm{P}$ release from primary afferents disappears in neuropathic pain but not inflammatory pain. Neuroscience, Elmsford, v. 267, p. 67-82, 2014.

CONDÉS-LARA, M.; ROJAS-PILONI, G.; MARTÍNEZLORENZANA, G.; LÓPEZ-HIDALGO, M.; RODRIGUEZJIMÉNES, J. Hypothalamospinal oxytocinergic antinociception is mediated by GABAergic and opiate neurons that reduce A-delta and $\mathrm{C}$ fiber primary afferent excitation of spinal cord cells. Brain Research, Amsterdam, v. 1247, p. 38-49, 2009.

D'ANGELO, R.; MORREALE, A.; DONADIO, V.; BORIANI, S.; MARALDI, N.; PLAZZI, G.; LIGUORI, R. Neuropathic pain following spinal Cord injury: what we know about mechanisms, assessment and management. European Review for Medical and Pharmacological Sciences, Rome, v. 17, n. 23, p. 3257-3261, 2013.

FIELDS, H. L., BASBAUM, A. I. Central nervous system mechanisms of pain modulation. In: WALL, P. D.; MELZACK, R. (Ed.). Textbook of pain. 4 ed, London: Churchill Livingstone, 1999. p. 309-329.

FONOFF, E. T.; DALE, C. S.; PAGANO, R. L.; TEIXEIRA, M. J.; BALLESTER, G.; GIORGI, R. Antinociception induced by epidural motor cortex stimulation in naive conscious rats is mediated by the opioid system. Behavioural Brain Research, Bethesda, v. 196, n. 1, p. 63-70, 2009.

FRANÇA, N. R. M.; TONIOLO, E. F.; FRANCIOSI, A. C.; ALVES, A. S.; ANDRADE, D. C.; FONODD, E. T.; BRITTO, L. R.; DALE, C. S. Antinociception induced by motor cortex stimulation: somatotopy of behavioral response and profile of 
neuronal activation. Behavioural Brain Research, Bethesda, v. 250, p. 211-221, 2013.

GASKELL, H.; MOORE, R. A.; DERRY, S.; STANNARD, C. Oxycodone for neuropathic pain and fibromyalgia in adults. The Cochrane Database of Systematic Reviews, Oxford, v. 6, CD010692, doi: 10.1002/14651858, 2014.

GHANBARI, A.; ASGARI, A. R.; KAKA, G. R.; FALAHATPISHE, H. R.; NADERI, A.; JORJANI, M. In vivo microdialysis of glutamate in ventroposterolateral nucleus of thalamus following electrolytic lesion of spinothalamic tract in rats. Experimental Brain Research, London, v. 232, n. 2, p. 415-421, 2014.

GUSTIN, S. M.; PECK, C. C.; CHENEY, L. B.; MACEY, P. M.; MURRAY, G. M.; HENDERSON, L. A. Pain and plasticity: is chronic pain always associated with somatosensory cortex activity and reorganization? The Journal of Neuroscience, Washington, v. 32, n. 43, p. 14874-14884, 2012.

HEAD, H.; HOLMES, G. Sensory disturbances from cerebral lesions. Brain Research, Amsterdam, v. 34, p. 102-254, 1911.

HUGHES, S. W.; HICKEY, L.; HULSE, R. P.; LUMB, B. M.; PICKERING, A. E. Endogenous analgesic action of the pontospinal noradrenergic system spatially restrict and temporally delays the progression of neuropathic pain following tibial nerve injury. Pain, Washington, v. 154, n. 9, p. 1680-1690, 2013.

JAGLA, G.; MIKA, J.; MAKUCH, W.; OBARA, I.; WORDLICZEK, J.; PRZEWLOCKA, B. Analgesic effects of antidepressants alone and after their local co-administration with morphine in a rat model of neuropathic pain. Pharmacological Reports, Kraków, v. 66, n. 3, p. 459-465, 2014.

JEON, Y.; KIM, C. E.; JUNG, D.; KWAK, K.; PARK, S.; LIM, D.; KIM, S.; BEAK, W. Curcumin could prevent the development of chronic neuropathic pain in rats with peripheral nerve injury. Current Therapeutic Research and Clinical, New York, v. 74, p. 1-4, 2013.

JIANG, L.; JI, Y.; VOULALAS, P. J.; KEASER, M.; XU, S.; GULLAPALLI, R. P.; GREENSPAN, J.; MASRI, R. Motor cortex stimulation suppresses cortical responses to noxious hindpaw stimulation after spinal cord lesion in rats. Brain Stimulation, New York, v. 7, p. 182-189, 2014.

KATAYAMA, Y.; TSUBOKAWA, T.; MAEJIMA, S.; HIRAYAMA, T.; YAMAMOTO, T. Corticospinal direct response in humans: identification of the motor cortex during intracranial surgery under general anaesthesia. Journal of Neurology, Neurosurgery, and Psychiatry, Minneapolis, v. 51, n. 1, p. 50-59, 1988.

KIM, J.; EUN LEE, S.; SIK MIN, K.; JUNG, H. H.; LEE, J. E.; KIM, S. J.; CHANG, J. W. Ventral posterolateral deep brain stimulation treatment for neuropathic pain shortens pain response after cold stimuli. Journal of Neuroscience Research, New York, v. 91, n. 7, p. 997-1004, 2013.

KIMURA, M.; SAITO, S.; OBATA, H. Dexmedetomidine decreases hyperalgesia in neuropathic pain by increasing acetylcholine in the spinal cord. Neuroscience Letters, London, v. 529, n. 1, p. 70-74, 2012.

KUMAR, N.; CHERKAS, P. S.; VARATHAN, V.; MIYAMOTO, M.; ChIANG, C. Y.; DOSTROVSKY, J. O.; SESSLE, B. J.; CODERRE, T. J. Systemic pregabalin attenuates facial hypersensitivity and noxious stimulus-evoked release of glutamate in medullary dorsal horn in a rodent model of trigeminal neuropathic pain. Neurochemistry International, Philadelphia, v. 62, n. 6, p. 831-835, 2013.

LU, Y.; DONG, H.; GAO, Y.; GONG, Y.; REN, Y.; GU, N.; ZHOU, S.; XIA, N.; SUN, Y. Y.; JU, R. R.; XIONG, L. A feed-forward spinal cord spinal cord glycinergic neural circuit Gates mechanical allodynia. Journal of Clinical Investigation, New York, v. 123, n. 9, p. 4050-4062, 2013.

MALCANGIO, M.; BOWERY, N.G. GABA and its receptors in the spinal cord. Trends in Pharmacological Sciences, London, v. 17, n. 12 , p. 457-462, 1996.

MAARRAWI, J.; PEYRON, R.; MERTENS, P.; COSTES, N.; MAGNIN, M.; SINDOU, M.; LAURET, B.; GARCIA-LARREA, L. Brain opioid receptor density predicts motor cortex stimulation efficacy for chronic pain. Pain, Washington, v. 154, p. 2563-2568, 2013.

MATSUO, H.; UCHIDA, K.; NAKAJIMA, H.; GUERRERO, A. R.; WATANABE, S.; TAKEURA, N.; SUGITA, D.; SHIMADA, S.; NAKATSUKA, T.; BABA, H. Early transcutaneous electrical nerve stimulation reduces hyperalgesia and decreases activation of spinal glial cells in mice with neuropathic pain. Pain, Washington, pii:S0304-3959, doi: 10.1016, 2014.

McQUAY, H. J. Neuropathic pain: evidence matters. European Journal of Pain, Headington, v. 6, Supl. A, p. 11-18, 2002.

MEYERSON, B.A.; LINDEROTH, B. Mode of action of spinal cord stimulation in neuropathic pain. Journal of Pain and Symptom Management, Madison, v. 4, Suppl: S6-12, 2006.

MILLAN, M. J. The induction of pain: an integrative review. Progress in Neurobiology, Paris, v. 57, n. 1, p. 1-164, 1999.

MOINI ZANJANI, T.; AMELI, H.; LABIBI, F.; SEDAGHAT, K.; SABETKASAEI, $M$. The attenuation of pain behavior and serum COX-2 concentration by curcumin in a rat model of neuropathic pain. Korean Journal of Pain, Seoul, v. 27, n. 3, p. 246-252, 2014.

OHARA, P. T.; VIT, J. P.; JASMIN, L. Cortical modulation of pain. Cellular and Molecular Life Sciences, Basel, v. 62, n. 1, p. 44-52, 2005.

OHNAMI, S.; KATO, A.; OGAWA, K.; SHINOHARA, S.; ONO, H.; TANABE, M. Effects of milnacipran, a 5-HT and noradrenaline reuptake inhibitor, on C-fibre-evoked Field potentials in spinal long-term potentiation and neuropathic pain. British Journal of Pharmacology, London, v. 167, n. 3, p. 537-547, 2012.

PAGANO, R. L.; ASSIS, V. A.; CLARA, J. A.; ALVES, A. S.; DALE, C. S.; TEIXEIRA, M. J.; FONOFF, E. T.; BRITTO, L. R. Transdural motor cortex stimulation reverses neuropathic pain in rats: a profile of neuronal activation. European Journal of Pain, Headington, v. 15, n. 3, p. 268, e.1-14, 2011.

PEYRON, R.; FAILLENOT, I.; POMARES, F. B.; LE BARS, D.; GARCIA-LARREA, L.; LAURENT, B. Mechanical allodynia in neuropathic pain. Where are the brain representations located? A positron emission tomography (PET) study. European Journal of Pain, Headington, v. 17, p. 1327-1337, 2013.

PORTILLA, A. S.; BRAVO, G. L.; MIRAVAL, F. K.; VILLAMAR, M. F.; SCHNEIDER, J. C.; RYAN, C. M. FREGNI, F. A feasibility study assessing cortical plasticity in chronic neuropathic pain following burn injury. Journal of Burn Care \& Research, Hagerstown, v. 34, n. 1, p. 48-52, 2013. 
REYNOLDS, D. V. Surgery in the rat during electrical analgesia induced by focal brain stimulation. Science, New York, v. 164, n. 808, p. 444-445, 1969.

RICHNER, M.; ULRICHSEN, M.; ELMEGAARD, S. L.; DIEU, R.; PALLESEN, L. T.; VAEGTER, C. B. Peripheral nerve injury modulates neurotrophin signaling in the peripheral and central nervous system. Molecular Neurobiology, Clifton, PMID: 244752592, doi: 10.1007/s12035-014-8706-9 2014.

RIDDER, D.; VANNESTE, S.; LAERE, K. V.; MENOVSKY, T. Chasing map plasticity in neuropathic pain. World Neurosurgery, New York, v. 80, n. 6, p. 901 e 01-05, 2013.

RIEDEL, W.; NEECK, G. Nociception, pain, and antinociception: current concepts. Zeitschrift für Rheumatologie, Nauhein, v. 60, n. 6, p. 404-415, 2001.

RISTOIU, V. Contribution of macrophages to peripheral neuropathic pain pathogenesis. Life Science, Bucharest, v. 93, n. 23, p. 870-881, 2013.

RUSINA, R.; VACULIN, S.; YAMAMOTOVA, A.; BAREK, S.; DVORAKOVA, H.; ROKYTA, R. The effect of motor cortex stimulation in deafferentated rats. Neuroendocrinology Letters, Prague, v. 26, n. 4, p. 283-288, 2005.

SAPIENZA, A.; GOAZIGO, A. R.; ROSTÈNE, W.; MÉLIKPARSADANIANTZ, S. Chemokines and attraction of myeloid cells in peripheral neuropathic pains. Biologie Aujourd'hui, Paris, v. 208, n. 1, p. 31-44, 2014.

SCHAIBLE, H. G. Spinal mechanisms contributing to joint pain. Novartis Foundation Symposium, Chichester, v. 260, p. 4-22, 2004.

SCHNITZLER, A.; PLONER, M. Neurophysiology and functional neuroanatomy of pain perception. Journal of Clinical Neurology, Philadelphia, v. 17, n. 6, p. 592-603, 2000.

SENAPATI, A. K.; HUNTINGTON, P. J.; PENG, Y. B. Spinal dorsal horn neuron response to mechanical stimuli is decreased by electrical stimulation of the primary motor cortex. Brain Research, Amsterdam, v. 2, n. 1-2, p. 173-179, 2005a.

SENAPATI, A. K.; LAGRAIZE, S. C.; HUNTINGTON, P. J.; WILSON, H. D.; FUCHS, P. N.; PENG, Y. B. Electrical stimulation of the anterior cingulated cortex reduces responses of rat dorsal horn neurons to mechanical stimuli. Journal of Neurophysiology, Arlington, v. 94, n. 1, p. 845-851, 2005 b.

SHRIVASTAV, M.; MUSLEY, S. Spinal cord stimulation for complex regional pain syndrome. In: Conference of the IEEE Engineering in Medicine and Biology Society, Piscataway, doi: 10.1109/IEMBS, 2009.

SRINIVASAN, V.; ZAKARIA, R.; JEET SINGH, H.; ACUNACASTROCIEJO, D. Melatonin and its agonists in pain modulation and its clinical application. Archives Italiennes de Biologie, Pisa, v. 150, n. 4, p. 274-289, 2012.

SUZUKI, R.; RAHMAN, W.; HUNT, S. P.; DICKENSON, A. H. Descending facilitatory control of mechanically evoked responses is enhanced in deep dorsal horn neurones following peripheral nerve injury. Brain Research, Amsterdam, v. 1019, n. 1-2, p. 6876, 2004.

THANGAMANI, D.; EDAFIOGHO, I. O.; MASOCHA, W. The anticonvulsant enaminone E139 attenuates paclitaxel-induced neuropathic pain in rodents. The Scientific World Journal, Nasr City, doi: 10.1155/2013/240508, 2013.
THIBAULT, K.; RIVALS, I.; M'DAHOMA, S.; DUBACQ, S.; PEZET, S.; CALVINO, B. Structural and molecular alterations of primary afferent fibres in the spinal dorsal horn in vincristineinduced neuropathy in rat. Journal of Molecular Neuroscience, Boston, v. 51, n. 3, p. 880-892, 2013.

TIWARI, V.; GUAN, Y.; RAJA, S. N. Modulating the delicate glialneuronal interactions in neuropathic pain: promises and potential caveats. Neuroscience \& Biobehavioral Reviews, Oxford, v. 10, n. 45C, p. 19-27, 2014.

TORRANCE, N.; SMITH, B. H.; BENNETT, M. I.; LEE, A. J. The epidemiology of chronic pain of predominantly neuropathic origin. Results from a general population survey. Journal of Pain, Chicago, v. 7, n. 4, p. 281-289, 2006.

TRISTER, R.; LANG, N.; KLEN, M. M.; OAKLANDER, A. L. Non-invasive transcranial magnetic stimulation (TMS) of the motor cortex for neuropathic pain - at the tipping point? Rambam Maimonides Medical Journal, Haifa, v. 4, n. 4, e.0023, 2013.

TSUBOKAWA, A. T.; KATAYAMA, Y.; YAMAMOTO, T.; HIRAYAMA, T.; KAYAMA, S. Motor cortex stimulation for control of thalamic. Pain, Washington, (Suppl) 5, p. 491, 1990.

TSUBOKAWA, T.; KATAYAMA, Y; YAMAMOTO, T.; HIRAYAMA, T.; KOYAMA, S. Chronic motor cortex stimulation in patients with thalamic pain. Journal of Neurosurgery, Charlottesville, v. 78, p. 393-401, 1993.

URBAN, M. O.; GEBHART, G. F. Supraspinal contributions to hyperalgesia. Proceedings of the National Academy of Sciences of the United States of America, Washington, v. 96, n. 14, p. 7687$7692,1999$.

VACULIN, S.; FRANEK, M.; YAMAMOTOVA, A.; ROKYTA, R. Motor cortex stimulation in rats with chronic constriction injury. Experimental Brain Research, London, v. 185, n. 14, p. 331-335, 2008.

VALLEJO, R.; TILLEY, D. M.; VOGEL, L.; BENYAMIN, R. The role of glia and the immune system in the development and maintenance of neuropathic pain. Pain Practice, Malden, v. 10, n. 3, p. 167-184, 2010.

VELASCO, F.; ARGÜELlES, C.; CARRILlO-RUIZ, J. D.; CASTRO, G.; VELASCO, A. L.; JIMÉNES, F.; VELASCO, A. M. Efficacy of motor cortex stimulation in the treatment of neuropathic pain: a randomized double-blind trial. Journal of Neurosurgery, Charlottesville, v. 108, p. 698-706, 2008.

WENG, H. R.; GAO, M.; MAIXNER, D. W. Glycogen synthase kinase 3 beta regulates glial glutamate transporter protein expression in the spinal dorsal horn in rats with neuropathic pain. Experimental Neurology, Orlando, v. 252, p. 18-27, 2014.

YEN, C. T.; LU, P. L. Thalamus and pain. Acta Anaesthesiologica Taiwanica, Taipei, v. 51, p. 73-80, 2013.

ZIMMERMANN, M. Pathobiology of neuropathic pain. European Journal of Pharmacology, Heidelberg, v. 429, n. 1-3, p. 23-37, 2001.

ZHANG, J.; DE KONINCK, Y. Spatial and temporal relationship between monocyte chemoattractant protein-1 expression and spinal glial activation following peripheral nerve injury. Journal of Neurochemistry, New York, v. 97, n. 3, p. 777-783, 2006. 